First Peoples Child \& Family Review

A Journal on Innovation and Best Practices in Aboriginal Child Welfare Administration,

Research, Policy \& Practice

\title{
THE FINAL WORD: After the Residential School Apology: Why All Canadians Should Care about a Racial Equality Case Before the Canadian Human Rights Commission
}

\section{Cindy Blackstock}

Volume 4, Number 1, 2009

URI: https://id.erudit.org/iderudit/1069353ar

DOI: https://doi.org/10.7202/1069353ar

See table of contents

Publisher(s)

First Nations Child and Family Caring Society of Canada

ISSN

1708-489X (print)

2293-6610 (digital)

Explore this journal

Cite this document

Blackstock, C. (2009). THE FINAL WORD: After the Residential School Apology: Why All Canadians Should Care about a Racial Equality Case Before the

Canadian Human Rights Commission. First Peoples Child \& Family Review, 4(1), 89-89. https://doi.org/10.7202/1069353ar 


\title{
After the Residential School Apology: Why All Canadians Should Care about a Racial Equality Case Before the Canadian Human Rights Commission
}

\author{
Cindy Blackstock, First Nations Child \& Family Caring Society
}

There is no way around it - if you are a First Nations child on reserve in Canada you simply get less government funding for statutory child welfare services than other children even though there are more First Nations children in child welfare care now than at the height of residential school operations. The federal government has failed to fully address the inequalities even after leading experts, including the Auditor General of Canada, have called for action. The Department of Indian Affairs (INAC) has publicly acknowledged that it's outdated funding formula results in growing numbers of First Nations children being removed from their families and placed in child welfare care. The Auditor General recently found that the federal government's new child welfare funding approach also fails to ensure equity.

These factors resulted in the Assembly of First Nations and the First Nations Child and Family Caring Society of Canada filing a complaint with the Canadian Human Rights Commission (CHRC) in February of 2007 alleging that the federal government's under funding of First Nations child welfare amounts to racial discrimination under the Canadian Human Rights Act.

Given that equality is a fundamental Canadian value and legal principle, it should have been in the joint interests of the federal government and First Nations to have an independent body such as the Canadian Human Rights Commission hear the case on its merits, forthwith.

However, since the Complaint was filed, the federal government has refused mediation twice and raised countless technicalities in an apparent effort to delay or derail the adjudication process. The federal government has gone so far as to question the jurisdiction of the Canadian Human Rights Commission to hear the case and the fairness of the Commission's investigative process. INAC's actions in this

Questions or correspondence concerning this article may be addressed to:

cblackst@fncfcs.com case lie in sharp contrast to INAC Minister Strahl's vigorous and public promotion of the CHRC in other forums such as the United Nations.

Despite the federal government's objections, on September 30, 2009 the Canadian Human Rights Commission formally considered the myriad of technical arguments raised by the federal government and ruled that case should be referred to inquiry before the Canadian Human Rights tribunal to be heard on it's merits.

In the last few days we were advised that the federal government is applying to the Federal Court of Canada to request that the child welfare human rights case be dismissed. The federal government basically argues that since they do not provide funding for non Aboriginal child welfare (the province does), the fact that the federal government provides so much less to First Nations children is not discrimination. This type of logic would defy the common sense and values of many Canadians who believe that children should not be deprived equitable services because of racial origin. There was no need for this delay, as the Tribunal could have entertained any further technical objections of the federal government at the time of the hearing.

Most disappointingly, we do not even know who in the federal government is instructing the lawyers at the Department of Justice - is it Prime Minster Harper? Minister Strahl? As Canadians, we simply do not know who actually instructs legal counsel at the Department of Justice. This vagueness leaves open the question of accountability when fundamental questions of racial discrimination affecting vulnerable children are at hand.

As Canadians, we should expect that when the federal government finds out about government legislation or policies that discriminate against children on the basis of race, they should move immediately to correct the problem. The federal government has not done so in these circumstances. Let's all call on the Prime Minister to immediately allow this case to be heard by the Canadian Human Rights Commission on its merits. 